and one female. Reared by terrier bitch, all died within a year. They wcre exhibited to King George IV. at the Royal Cottage, Windsor, on November I, 1824 .

Second Litter.-Born April 22, 1825, at Clapham Common; there were three cubs, sexes not recorded. Reared by the mother, as also were all the subsequent litters. They only lived a short time.

Third Litter, - Born December 31, 1826 or '27, at Edinburgh, one male and two females. As stated in the previous paper, the year is given as 1827 in the handbill of the menagerie from which I quoted, and the other references seem to support that date; but Mr. John Atkins says it is given as 1826 in a printed catalogue in his possession.

Fourth Litter.-Born Oetober 2, 1828, at Windsor, one male and two females.

Fifth Litter.-Born May, 1831, at Kensington, three cubs, sexes not recorded. They were shown to the Queen, then Princess Victoria, and to the Duchess of Kent. The whole group performed in a specially constructed cage at Astley's Amphitheatre, and in 1832 were taken by Mr. Atkins for a tour in Ireland. To a separate aceont of this tour reference has been made in my previous paper.

Sixth Litter,-Born July 19, I833, at the Zo slogical Gardens, Liverpool, one male and two females. One, the male, lived for ten years in the gardens. The young male !ion-tigers when about three years old had a short mane something like that of an Asiatic lion; the stripes became very indistinct at that age.

Mr. Atkins informs me that there is a badly stuffed specimen of one cub which was about a year old in the Museum at Salisbury, and from Mr. Harmer's letter (see Nature, p. 4'3) there is one also in Cambridge.

From the account quoted by him it would seem improbable that that particular specimen, had it survived, could have bred. As a matter of fact I learn from Mr. $\Lambda$ tkins that none of them ever did breed, though he does not know of any reason why they should not have done so.

Mr. Atkins thinks that the cubs of the earlier litters died from over-feeding; when he adopted a different treatment he had no difficulty in rearing them.

In my previous paper, in the quotation from Griffiths, the word "superfineness" should read "superficies."

This record, it may be noted, while correcting some.errors in the previously published accounts, also extends over a period subsequent to all of them.

Science and Art Museum, Dublin, April r 5.

\section{Soot-figures on Ceilings.}

As the subject of dust-images was recently considered in some interesting letters in NATURE, I wish to record an example of a soot-image which was far more detailed and remarkable than any $I$ have yet seen. The example is to be found on the ceiling of the billiard-room in the Golf Club House at Felixstowe. Abundant soot has been deposited abuve the lamps by which the table is lighted, and this is distributed so as to map out on the ceiling not only the outline of the joists, but that of the laths and even of the nails by which the ends of the latter are secured, The mark corresponding to the nail-head is certainly much larger

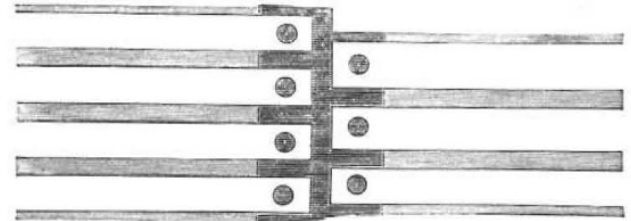

than the latter. I made rom memory a rough sketch of the appearance, which is reproduced in the accompanying woodcut. I may be mistaken in the position of some of the light and dark shades. If the example is as new to others as it was to me it would be interesting to have a photograph of the ceiling bafore it is again whitewashed.

Oxford, April 17 .

E. B. POUL'ToN.

THis phenomenon is often observed, though not often so clearly as in the case noticed by Mr. Poulton. It is due to the same cause as produces the dust-free space seen rising from hot bodies in illuminated smoky air, viz. a peculiar Crookesian (or rather Osborne Reynoldsian) bombardment of sufficiently No. [ 226 , vOL. 47 ] small dust-particles, in the direction of decreasing temperature, by the extra energy of the gas-molecules on one side See papers by myself and the late Mr. Clark in Nature (especially July 26, 1883, April 24, 1884, vol, xxix. p. 417, and January 22, 1885), and in Phil. Mag., 1884, Proc. R.I., \&c. ; also by Mr. Aitken, Trans. R.S. Edin,, 1884. And see the remarkable theoretical paper by l'rof. Osborne Reynolds on "Dimensional Properties of Gases," Phil. Trans., 1879.

Dust gets bombarded out of hot air on to all colder surfaces. The details of this effect are specially given by Mr. Aitken in NATURE, vol. xxix. p. 322. The badly-conducting plaster of a ceiling is no doubt fully heated by contact with the air below except in places where the conducting power of wood or iron keeps it comparatively cool ; hence the picking-out of the pattern. Solid deposit from warm air on to cool surfaces can occur without any actual smoke; e.g. it can be noticed above incand escent lamps. OLIVER LODGE.

\section{The Use of Ants to Aphides and Coccidre.}

I HAVE just had an opportunity of seeing Dr. R imanes' in teresting work, "Darwin, and after Darwin," and find therein (p. 292) the production of honey-dew by Aphides adduced as a difficulty in the way of the Darwinian theory. I have not prid any particular attention $t$, A phides, but have lately been much interested in the allied Coccidæ, which, since they produce a similar fluid attracting ants, may be considered to off sr a parallel instance, Buth Coccidx and Aphides suffer from many predaceous and parasitic enemies, and there seems to be no doubt that the presence of numerous ants serves to ward these off, and is consequently beneficial. There is an interesting Caccid, Iceryo rose , which I find on Prosopis here, and on more than one occasion I have been unable to collect specimens without being stung by the ants. At the present moment soma of these Icerye are enjoying life, which would certainly have perished at my hands, but for the inconvenience presented by the numbers of stinging ants.

Belt and Forel have also written on the protection of Coccidx by ants ("Naturalist in Nicaragua ;" and Bull. Soc. Vaul., 1876). Maskell has given an account of the honey-dew organ of Coccide, from which it appears that it is something more than a mere organ for the excretion of waste products. This author also figures some of the fungi which grow on honey.dew, and it may well be that these also serve to prevent the attacks of enemies. When, as we sometimes see in Jamaica, the leaves appear to be coated with soot (Antennaria robbinsii is the fungus) it cannot be so convenient for coccinellid larvæ, Chrysopa larvæ, $\& c .$, to crawl about on them in search of Coccidæ.

Jamaica, April 3 .

T. D. A. COCKERELL.

\section{Blind Animals in Caves.}

IN his last letter (p. 537) Mr. J. T. Cunninghan states that the "early stages" of the European Proteus have not yet been obtained. This assertion is incorrect. In 1888 and 1889 the oviposition and development have been deicribed by E. Zeller (Zool. Anz., 1888, No. 290, and Fahresh. VEr. Naturk. Wiurt., xlv., 1889 , p. 131, plate iii.), who gives a coloured figure of the larva, and particularly refers to the development of the eyes. As early as 1831 (Oken's "Isis," 1831, p. 50I) Michahelles remarked that the eyes in young. specimens are more distinct and somewhat larger than in the adult.

G. A. BoUlenger.

\section{OBSERVATIONS IN THE WEST INDIES:}

H ERE we are back at Nassau for the third time, and H thinking you might be interested to hear of my cruises, I send you a short sketch of our trip. The first time we left Nassau we entered the Bahama Bank at Douglass Channel and crossed the bank to North Eleuthera, where we examined the "Glass Window" and the northern extremity of Eleuthera, we then sailed along the west shore of the island close enough to get a good view of its characteristics as far as Rock Harbour at the

1 A letter from Alexander Agassiz to J. I'. Dana; dated Steam Yacht Wild Duck, Nassau, March, 1893 . Printed in the American Jaurnal of Science for April, and communicated to NATURE by the author. 
southern end. We steamed out into Exuma Sound through the Powell Channel and round the southern end of Eleuthera to little San Salvador, and the north-west end of Cat Island, where are the highest hills of the Bahamas. We then skirted Cat Island along its western face, rounded the southern extremity and made for Riding Rocks on the Western side of Watling's Island. We circumnavigated Watling, passed over to Rum Cay, then to northern part of Long Island, visiting Clarence Harbour; next we crossed to Fortune Island, and passed to the east side near the northern end of the island on the Crooked Island Bank. From there we crossed to Caicos Bank, crossing that bank from French Cay to Long Island, passed by Cockburn Harbour and ended our eastern route at Turks Island; from there we shaped our course to Santiago de Cuba to coal and provision the yacht. We were fortunate enough to strike Cape Maysi a short time after daylight, and I thus had a capital chance to observe the magnificent elevated terraces (coral reefs) which skirt the whole of the southern shore of Cuba from Cape Maysi to Cape Cruz and make so prominent a part of the landscape as seen from the sea. We were never more than three miles from shore and had ample opportunity to trace the course of some of the terraces as far as Santiago, and to note the great changes in the aspect of the shores as we passed westward due to the greater denudation and erosion of the limestone hills and terraces to the west of Cape Maysi, which seems to be the only point where five terraces are distinctly to be seen. The height of the hills east of Pt. Caleta, where the terraces are most clearly defined, I should estimate at 900 to 1000 feet; though the hills behind the terraces, which judging from their faces are also limestone, reach a somewhat greater height, perhaps I IOO to I 200 feet.

After coaling at Santiago de Cuba we visited Inagua. and next steamed to Hogstey Reef, a regular horseshoeshaped atoll with two small cays at the western entrance. There we passed three days studying the atoll. This to me was an entirely novel experience; to be at anchor in 3 fathoms of water 45 miles from any land with water goo fathoms within three miles outside, surrounded by a wall of heavy breakers pounding upon the narrow annular reef which sheltered us. I made some soundings in the lagoon and on the slope of reef outside. From there we returned to Crooked Island Bank to the westward of which I also made some soundings to determine the slope of the Bank. We next again visited Long Island, taking in the southern and northern ends which I had not examined. From there we passed to Great Exuma, stopping at Great Exuma Harbour and sounding into deep water on our way out to Conch Cut when we sailed west crossing the Bank to Green Cay. From there we made the southward face of New Providence, and before going into Nassau Harbour made some trials in deep water in the Tongue of the Ocean with the Tanner deepsea townet in 100 and 300 fathoms, depth being 700 fathoms-after which we returned to Nassau. I had on board a Tanner sounding machine kindly loaned me for this trip by Colonel McDonald of the Fish Commission, and some deep-sea thermometers were also kindly supplied by him and by Prof. Mendenhall, the superintendent of the U.S. Coast Survey. I supplied myself with a number of Tanner deep-sea townets and with a supply of dredge and of townets and carried on board a Yale and Towne patent winch for winding the wire rope which I used in my dredging and towing in deep water. The yacht was provided with a steam capstan and by increasing its diameter with lagging we found no difficulty in hauling in our wire rope at the rate of $8 \mathrm{~min}$. to 100 fathoms. I carried 600 fathoms of steel wire dredging rope with me of the same dimensions which I had used on the Blake and which has also been adopted on the Albatross. During our second cruise we steamed from Nassau for Harvey Cay crossing the Bank NO. I 226 , voL. 47] from north to south to Flamingo Cay, and then to Great Ragged Cay, from which we took our departure for Baracoa: At Baracoa I hoped to be able to ascend the Yunque ; unfortunately I had to give up my trip owing to the desperate condition of the roads. From Baracoa we steamed close to the shores to the westward, touching at Port Banes, Port Padre, Cay Confites, Sagua, Cape Frances, Cardenas, Matanzas, and finally ending at Havana. This trip was a continuation of the observa tions we made on the south coast of Cuba and enabled me to trace the gradual disappearance of the terraces from Baracoa to Nuevitas, and their reappearance from Matanzas to Havana, from the same causes which evidently influenced their state of preservation from Cape Maysi west. I also got a pretty clear idea of the mode of formation of the fine harbours found on the northern coast of Cuba to the eastward of Nuevitas, and of the mode of formation of the extensive systems of cays reaching from Nuevitas to Cardenas and which find their parallel on the south coast of Cuba from Cape Cruz to Cape Corrientes. After refitting at Havana we left for Nassau. Both on going into Havana and on leaving we spent the greater part of a day in towing with the Tanner net. I thought I could not select a better spot for finally settling the vertical distribution of pelagic life than off Havana which is in deep water-900 fathoms -close to land, on the track of a great oceanic current, the Gulf Stream, noted for the mass of pelagic life it carries along its course. We towed in 100, 150, 250, and 300 fathoms and on the surface at or near the same locality, and I have found nothing to cause me to change the views which I expressed in my preliminary reports of the Albatross expedition of 1891 . Nowhere did I find anything which was not at some time found also at the surface. At 100 fathoms the amount of animal life was much less than in the belt from Ioo fathoms to the surface. At 150 fathoms there was still less and at $25^{\circ}$ fathoms and 300 fathoms the closed part of the Tanner contained nothing. At each one of these depths we towed fully as long as was required to bring the net to the surface again. Thus we insured before the messenger was sent to close the lower part of the bar as long a pull through water as the open part of the net would have to travel till it reached the surface, giving the fauna of a horizontal column of water at 100, I50, 250 , and 300 fathoms of the same or greater length than the vertical column to the surface for comparison of their respective richness. From Havana we steamed to Cay Sal Bank, visited Cay Sal, Double-headed Shot Cays, Anguila Islands, and then crossed over to the Great Bank to the west of Andros Island. The bottom of this bank is of a most uniform level, 3 and $3^{\frac{1}{2}}$ fathoms for miles and then very gradually sloping to the west shore of Andros, so that we had to anchor nearly six miles from the "Wide Opening" of the central part of Andros which we visited. The bottom consists of a white marl, resembling when brought up in the dredge newly mixed plaster of Paris, and having about its consistency just as it begins to set. This same bottom extends to the shore; and the land itself, which is low where we went on shore not more than IO to I 5 inches above high-water mark, is made up of the same material, which feels under foot as if one were treading upon a sheet of soft india rubber; of course on shore the marl is drier and has the consistency of very thick dough. It appears to be made up of the same material as the æolian rocks of the rest of the Bahamas, only that it has become thoroughly saturated with salt water, and in that condition it crumbles readily and is then triturated into a fine impalpable powder almost like deep sea ooze which covers the botton of the immense bank to the west of Andros. After leaving Andros we crossed the bank again to Orange Cay and followed the eastern edge of the Gulf Stream to see Riding Rocks, Gun Cay, and the Beminis. We then passed to Great Isaac, where we saw some huge 
masses of xolian rocks which had been thrown up along the slope of the cay about 80 feet from high-water mark to a height of 20 feet. One of these masses was $15^{\prime} 6^{\prime \prime} \times$ I I" $\times 6^{\prime}$. We then kept on to Great Stirrup Cay coasting along the Berry Cays, crossed over to Morgan's Bluff, on eastward of Andros down to Mastic Point on the same Sound, and then returned to Nassau.

The islands of the Bahamas (as far as Turks Island) are all of eolian origin. They were formed at a time when the Banks up to the ro-fathom line must have been practically one huge irregularly shaped mass of low land, from the beaches of which successive ranges of low hills, such as we still find in New Providence, must have originated. After the islands were thus raised there was an extensive gradual subsidence which can be estimated at about 300 feet, and during this subsidence the sea has little by little eaten away the acolian lands, leaving only here and there narrow strips of land in the shape of the present islands. Inagua and Little Inagua are still in the original condition in which I imagine such banks as the Crooked Island Banks, Caicos Banks, and other parts of the Bahamas to liave been; while the process of disintegration going on at the western side of Andros shows still a broad island which will in time leave only the narrow eastern strip of higher land (æolian hills) on the western edge of the tongue of the ocean. Such is the structure also of Salt Cay Bank which owes its present shape to the same conditions as those which have given the Bahamas their present configuration. My reason for assigning a subsidence of 300 feet is the depth of some of the deep holes which have been surveyed on the bank and which I take to be submarine blow-holes or caverns formed in the aelian limestone of the Bahama hills when they were at a greater elevation than now. This subsidence explains satisfactorily the cause of the present configuration of the Bahamas, but tcaches us nothing in regard to the substratum upon which the Bahamas were built. The present reefs form indeed but an insignificant part of the topography of the islands and have taken only a secondary part in filling here and there a bight or a cove with more modern reef rock, thrown up against the shores so as to form a coral reef beach such as we find in the Florida Reef. I have steamed now nearly 3300 miles among the Bahamas, visiting all the more important points and have made an extensive collection of the rocks of the group.

I hoped to have made also a larger number of deep soundings than I have been able to take; unfortunately the trades were unusually heavy during the greater part of my visit to the Bahamas, greatly interfering with such work on a vessel no larger than the Wild Duck - I 27 feet on the water line. For the same reason the number of deep-water pelagic hauls was also much smaller than 1 hoped to make, as in a heavy sea the apparatus would have been greatly endangered. It is a very different thing to work at sea in a small yacht like the Wild Duck or in such vessels as the Blake and the Albalross of large size and fitted up with every possible requirement for decp sea work. The Wild Duck, on the other hand, was admirably adapted for cruising on the Bahama Banks, her light draught enabling her to go to every point of interest and to cross and recross the banks where a larger vessel could not follow. I am under the greatest obliga. tions to my friend Mr. John M. Forbes for having so kindly placed his yacht at my disposal for this explora. tion, and I hope soon after my return to Cambridge to publish more in detail the results of this cxamination of the structure of the Bahamas.

ARTIONYX - A CLAWED ARTIODACTYLE.

$\mathrm{IF}$ any further evidence were needed to disprove Cuvier's famous generalisation, it is found in the recently discovered hind foot of Artionyx. In this foot each of the digits with all the phalanges are modified very much as in the primitive bears, and combined with metatarsals and an ankle joint almost identical with those of the pigs. The termination of the limb in claws would have led Cuvier to predict that the whole skeleton and the dentition was of a clawed or carnivorous type, whereas in this animal we find the foot alone belongs to two types as widely separated as can be, and the probabilities are that the skeleton and teeth are also mixed in character.

The foot of Artionyx was found last summer by the American Museum party under Dr. Wortman, in the same beds with the remarkablc Protoceras recently described in NATURE. It belonged to an animal about the size of a peccary. The terminal claws were first exposed, and although found uncleft, they at once suggested a reference to Chalicotherium, for which the party was keeping a sharp look-out; but a further removal of the matrix showed a pes of an entirely distinct character. In the foot of Chalicotherium magnum of the Upper Miocene of France we find three toes, thus odd in number, but not strictly perissodactyle, for the largest is
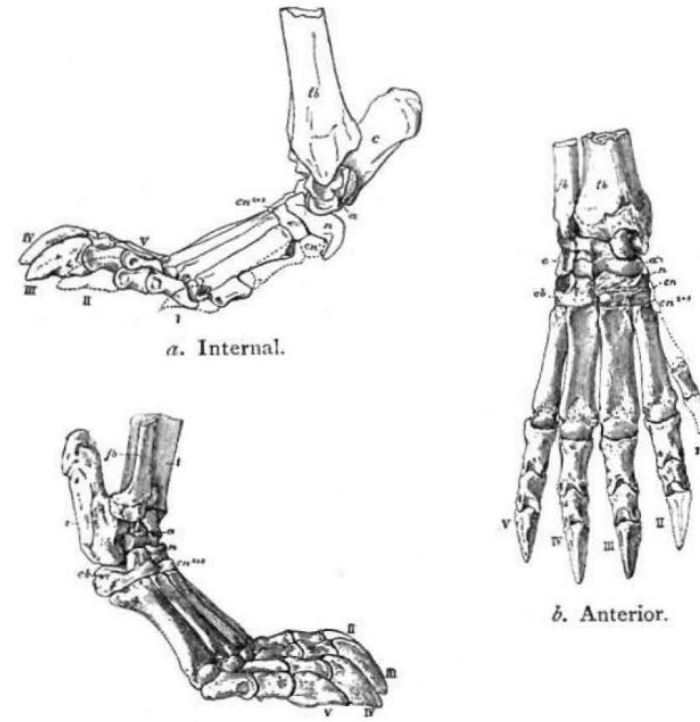

b. Anterior.

$$
\begin{aligned}
& \text { c. External. } \\
& \text { Right hind foot of Artionyx gaudryi. }
\end{aligned}
$$

not the median but the outer toe. Above the toes is an ankle joint of a modified perissodactyle type, that is, the astragalus is grooved upon its tibial side, and flattened where it rests upon the navicular. The navicular and cuneiforms are also flattencd, so that the foot must have been placed somewhat at an angle with the leg, as it is in the Sloths. In Artionyx, on the other hand, there are five digits; the first, or thumb, was a dew-claw, very much shorter than the rest; the rcmaining four, as shown in $b$ of the figure, are nearly symmetrically placed in pairs on either side of the median line, precisely as in the Artiodactyla. This has suggested the name of the animal, its even-numbered toes terminating in claws. Above these elements we have a coalescence of the outer and middle cuneiforms as in many $\Lambda$ rtiodactyla. The cuboid, navicular, astragalus, and calcaneum, are also modified precisely as in the artiodactyles. The fibula comes down upon the heel bone, and there is the characteristic double hinge. The tibia is strongly interlocked on the outer side of the astragalus. The three accompanying cuts exhibit the peculiar features of this foot; the side views showing that the animal was digitigrade like the cats, and not plantigrade like the bears, although the claws were more of the bear than the cat type. No. 1226 , vor. 47$]$ 